\title{
Effects of Soil Abiotic and Biotic Factors on Tree Seedling Regeneration Following a Boreal Forest Wildfire
}

\author{
Theresa S. Ibáñez, ${ }^{1 *} \odot$ David A. Wardle, ${ }^{2} \odot$ Michael J. Gundale, ${ }^{1} \odot$ and \\ Marie-Charlotte Nilsson ${ }^{1} \odot$
}

\begin{abstract}
${ }^{1}$ Department of Forest Ecology and Management, Swedish University of Agricultural Sciences, Umeå, Sweden; ${ }^{2}$ Asian School of the
\end{abstract} Environment, Nanyang Technological University, Singapore, Singapore

\begin{abstract}
Wildfire disturbance is important for tree regeneration in boreal ecosystems. A considerable amount of literature has been published on how wildfires affect boreal forest regeneration. However, we lack understanding about how soil-mediated effects of fire disturbance on seedlings occur via soil abiotic properties versus soil biota. We collected soil from stands with three different severities of burning (high, low and unburned) and conducted two greenhouse experiments to explore how seedlings of tree species (Betula pendula, Pinus sylvestris and Picea abies) performed in live soils and in sterilized soil inoculated by live soil from each of the three burning severities. Seedlings grown in live soil grew best in unburned soil. When sterilized soils were reinoculated with live soil, seedlings of $P$. abies and $P$. sylvestris grew better in soil from low burn severity stands than soil from either high severity or unburned stands, demonstrating that fire dis-
\end{abstract}

Received 3 September 2020; accepted 30 May 2021; published online 6 July 2021

Supplementary Information: The online version contains supplementary material available at https://doi.org/10.1007/s10021-021-0066 6-0.

Author contributions All four authors planned and designed the research. TSI performed experiments and analyzed the data with support from DAW and MJG. TSI wrote the first draft of the manuscript, and all authors contributed substantially to revisions and gave final approval for publication. MCN administered the project and also acquired the funding. *Corresponding author; e-mail: theresa.ibanez@slu.se turbance may favor post-fire regeneration of conifers in part due to the presence of soil biota that persists when fire severity is low or recovers quickly post-fire. Betula pendula did not respond to soil biota and was instead driven by changes in abiotic soil properties following fire. Our study provides strong evidence that high fire severity creates soil conditions that are adverse for seedling regeneration, but that low burn severity promotes soil biota that stimulates growth and potential regeneration of conifers. It also shows that speciesspecific responses to abiotic and biotic soil characteristics are altered by variation in fire severity. This has important implications for tree regeneration because it points to the role of plant-soil-microbial feedbacks in promoting successful establishment, and potentially successional trajectories and species dominance in boreal forests in the future as fire regimes become increasingly severe through climate change.

Key words: Abiotic and biotic soil characteristics; Betula pendula; Boreal forest; Burn severity; Climate change; Picea abies; Pinus sylvestris; Plant-soil interactions; Tree seedling regeneration; Wildfire. 


\section{HighLIGHTS}

- High burn severity created conditions adverse for seedlings growth.

- Low burn severity promoted soil biota that enhanced growth of Pinus sylvestris and Picea abies.

- Betula pendula growth was driven by changes in abiotic soil properties.

\section{INTRODUCTION}

Fire is a recurrent natural disturbance in northern coniferous forests that controls vegetation dynamics, structure, diversity and function. While boreal forests are shaped by and adapted to fire, natural fire regimes are rapidly changing as a consequence of global climate change (Kasischke and Turetsky 2006; Soja and others 2007; Balshi and others 2009; Ponomarev and others 2016). For many parts of the boreal region, burn probability, fire area and fire intensity are projected to increase and become more common as the climate warms (de Groot and others 2013). This is in part due to increasing duration of extreme fire-promoting conditions, such as warmer temperatures (Gillett and others 2004). These changes in fire regime are predicted to alter plant and soil community structure and cause elevated tree mortality (Stephens and others 2013), alter soil organic matter content (Czimczik and others 2005) and alter functioning of soil microbial communities due to increased loss of organic material (Allison and Treseder 2011). More frequent and higher intensity fires are also likely to induce shifts in how boreal forests will regenerate and recover from fire disturbances (Johnstone and others 2010; Alexander and others 2018), in part as a consequence of fire-induced effects on loss of soil organic matter and survival of mycorrhizal fungi needed for tree seedling regeneration (Dahlberg and others 2001; Dahlberg 2002).

Fires in boreal forests of Eurasia typically occur as low-intensity ground surface fires, to which many of the dominant tree species are adapted (Angelstam and Kuuluvainen 2004). In Sweden, older Scots pine (Pinus sylvestris) trees frequently survive ground fire because of their thick bark and high crown base height (Zackrisson 1977; Hellberg and others 2003), and deciduous trees such as birch (Betula pendula and Betula pubescens) are well adapted to ground fires because the high position of the crown and their ability to resprout vegetatively after fire (Atkinson 1992). In contrast, Norway spruce (Picea abies) trees are usually consumed by fire because of their thin bark and low branches (Zackrisson 1977). Post-fire regeneration by P. sylvestris and $B$. pendula occurs from seeds that are dropped on site shortly after fire from surviving trees, and seeds of $B$. pendula can also be spread over long distances, while $P$. abies typically recolonizes slowly post-fire by seeds originating from outside burned areas. (Granström 1991; Hellberg and others 2003). Fire is often necessary for new forest tree cohorts to regenerate in these ecosystems (Lampainen and others 2004), and this is associated with the reduction or loss of understory vegetation and shifts in soil properties such as increased concentrations of inorganic nitrogen (that is, $\mathrm{NH}_{4}{ }^{+}$) (DeLuca and others 2002; Gómez-Rey and Gonzalez-Prieto 2013). However, the extent of post-fire tree regeneration is also regulated by soil burn severity (Bansal and others 2014), because higher severity burns cause greater loss of organic material and soil biota (Certini 2005) and higher mortality rates of trees which may lead to slower tree regeneration. Although much is already known about the impact of fire on plant mortality and post-fire successions in boreal forests, less is known about how variation in fire behavior and tree mortality impacts aboveground-belowground linkages and soil microbial communities, which may have important consequences for forest regeneration (but see Bergner and others 2004; Treseder and others 2004; Holden and others 2013; Sun and others 2015; Hewitt and others 2020).

Soil microorganisms, and notably saprotrophic microbes and ectomycorrhizal fungi, are critical components for nutrient turnover and seedling establishment and growth in boreal forest (Read and others 2004), and their response to fire disturbance can therefore impact on post-fire recovery of trees (Hewitt and others 2017). The extent to which the organic layer is combusted or lost from fire has major impacts on the soil biota and the speed of its post-fire recovery. Communities of ectomycorrhizal fungi can survive low burn severity fires when the organic layer is not completely consumed (Dahlberg 2002; Holden and others 2016). Survival and short-term recovery of ectomycorrhizal fungi may, however, depend not only on the remaining organic layer, but also on the degree of fire-induced mortality of overstory trees (Dahlberg 2002; Pérez-Izquierdo and others 2021). With regard to saprotrophic soil microbes, bacteria in general appear to be more resistant than fungi to fire because they are better adapted to resist fire-generated heat (Certini 2005; MataixSolera and others 2009). The release of organic 
nutrients after fire can stimulate the recovery rate of bacterial communities (Bárcenas-Moreno and others 2011), leading to accelerated short-term release of inorganic soil nutrients that favors tree regeneration. In contrast, higher burn severity may strongly reduce the microbial communities and thereby soil organic matter decomposition, reducing the availability of nutrients needed for tree growth (Holden and others 2016). In total, tree seedling responses to fire depend on how the fire affects both the soil microbes and the abiotic soil properties, as well as the interaction between them. However, the effects of belowground biotic and abiotic changes caused by fire on tree seedling regeneration have mostly been investigated in isolation from one another.

On 31 of July 2014, a large accidental wildfire in east-central Sweden, known as the Västmanland burn started (Gustafsson and others 2019). It was initiated and spread fast due to an extended period of unusually hot and dry weather; it burned more than 13,000 ha of forest and was the largest fire in Swedish modern history (Lidskog and others 2019). For a large part of this area, the fire was intense and caused widespread tree death and loss of the organic layer. Within this area, some forest stands were severely burned, some stands were less severely burned, and some stands were not burned at all, creating a mosaic of stands across the landscape with differing fire severity. We collected soils from forest stands of low burn severity, high burn severity and unburned stands for use in each of two greenhouse experiments that were set up to better understand how growth of three different seedling species (P. abies, P. sylvestris, B. pendula) respond to different burn severities. In the first greenhouse experiment we planted seedlings in live (nonsterile) soil from each burn severity class, and the difference in seedling growth between burn severity treatments could be due to either soil abiotic properties (that is, $\mathrm{pH}$, nutrients, organic matter content, or texture) or biotic properties (that is, composition and biomass of organisms present); this experiment did not allow us to disentangle the role of these two mechanisms. In the second greenhouse experiment, we planted seedlings in sterilized soils that had been inoculated with live soil (that is, containing live soil biota) from each stand burn severity class. Doing this allowed us to separate how soil abiotic versus biotic properties influenced seedling growth and thus shed insights into the mechanisms underpinning the first experiment.

Through these two experiments, we sought to test how the abiotic and biotic components of soil impact tree seedling growth when soils are subjected to different levels of burn severity. For the first experiment, we hypothesized that seedlings will grow better in living soil from stands subjected to low burn severity relative to soils from either unburned or high burn severity stands. We expected this because burning would enhance nutrient availability (Wan and others 2001), and mild burning would enhance nutrient availability without impairing the ectomycorrhizal fungal community or stimulate succession of fire adapted fungal species. Further, we expected this effect to be greater for pioneering fast-growing species $(P$. sylvestris and $B$. pendula) that can better exploit these inorganic resources relative to late-successional species (P. abies) because of their rapid root growth and photosynthesis (Pumpanen and others 2009; Nilsson and others 2012). For our second experiment, we hypothesized that tree seedlings planted in sterilized soils would grow the largest when inoculated with soil from stands with live trees present (that is, stands subjected to low severity burning or unburned stands), and that this would occur irrespective of the burn severity class of the sterilized soil. We expected this because high burn severity soils should mostly lack live tree roots (Pérez-Izquierdo and others 2019) and thus are unlikely to harbor a living ectomycorrhizal fungal community (Dahlberg 2002; Pérez-Izquierdo and others 2021) that is essential for plant nutrient acquisition (Smith and Read 2008). Further, we expected that the positive effect of inoculation with unburned or low burn severity soils would be greatest for $P$. sylvestris seedlings because it was the dominant tree cover in these stands before and after fire, and would likely promote an ectomycorrhizal community that is most suitable for $P$. sylvestris and includes fire-adapted early colonizing fungi. Additionally, we would expect conifers to benefit from late-successional fungi present in unburned soils. Testing these hypotheses in combination contributes to a mechanistic understanding of how tree regeneration success following wildfire varies in response to burn severity in boreal forests, and how this is determined by abiotic versus biotic soil properties.

\section{MeThodS}

\section{Selection of Burn Severity Stands}

Within the Västmanland burn, we selected 25 burned forest stands that were each about 0.25 ha and had undergone one thinning operation prior to the fire (stem density of $<1000$ stems per hec- 
tare); they were all on podzolized soils, had a site index of 22-24 $\mathrm{m}$ (that is, the estimated dominant height at age 100 years) and represented a gradient in burn severity. They occurred within an area of approximately $60 \mathrm{~km}^{2}$, with each stand separated at least $300 \mathrm{~m}$ from all other stands. Prior to the fire, the stands were dominated $(87 \%)$ by $40-50$ year-old Scots pine (P. sylvestris) production forests with scattered (11\%) Norway spruce (P. abies) and $(2 \%)$ birch (Betula spp.) trees and an understory vegetation dominated by ericaceous dwarf shrubs (Vaccinium vitis-idaea, V. myrtillus and Calluna vulgaris) and mosses (mainly Pleurozium schreberi).

In April 2016, data for stand characteristics of the 25 burned stands were collected within a circular plot of $314 \mathrm{~m}^{2}$ (radius $=10 \mathrm{~m}$ ) in the center of each stand. Tree mortality was determined by visual inspection (for example, the lack of green needles present) and calculated as the percentage of dead trees versus all (dead and alive) trees within the plot. The number of trees with stem scorch visible (for example, trees that had bark that had fallen off the stem) was also counted. Flame length was determined as the average charring height of stems for 20 P. sylvestris trees per plot, and for these, the level of crown scorching (that is, the proportion of needles killed or consumed by fire throughout the whole crown) was also estimated. For each plot, the total organic (humus) depth (that is, Oa and Oe horizons) and the depth of the charred layer in the soil profile were measured at 25 random positions by vertically inserting a ruler in the ground. In addition, in four randomly allocated positions within each plot, the amount of charcoal deposited on the topsoil was collected within a circular area (radius $=8 \mathrm{~cm}$ ) and converted to dry mass per area. With the use of these data (that is, tree mortality, flame height, stem scorch, crown scorch, humus depth, depth of charred soil, coarse charcoal on surface and fine charcoal on surface) for each of the 25 stands, we then classified the stands into burn severity classes by using Principal Component Analysis (PCA) followed by K-mean clustering. From this analysis we selected seven stands of high burn severity and seven stands of low burn severity for further use (Supporting Information Figure S1; Table S1). The major differences between high burn and low burn severity stands result from high burn stands having a higher tree mortality, larger flame height, a higher number of stem and crown scorches of trees and a larger reduction of humus thickness from humus combustion (Table 1). In addition, seven unburned stands distributed around the burned area (within $500 \mathrm{~m}$ of the fire perimeter) were also selected for this study. The three burn severity class stands (unburned, high burned and low burned in total 21 stands) were randomly distributed across the burned area, allowing each stand to serve as an independent replicate, with seven randomly distributed stands in each burn severity class. Prior to the fire, there were no major differences in mean tree height, tree basal area, tree biomass or tree species composition among burn severity classes (Pérez-Izquierdo and others, Unpublished Manuscript).

\section{Soil Chemistry of Forest Stands}

On May 22-26, 2018 we randomly collected five circular soil cores of mineral soil (radius $=5 \mathrm{~cm}$; depth $=10 \mathrm{~cm}$ ) and five circular soil cores of the organic layer (radius $=15 \mathrm{~cm}$ ) to the full organic layer depth from each 21 stands. The organic $(\mathrm{hu}-$ mus) layer included the Oa and Oe horizon, while the Oi horizon was excluded from the soil samples. The five soil cores were bulked to represent one sample per stand. Roots and small debris were removed from the soil. For a subsample of each sample, the total concentration of phosphorus (P) was determined by Kjeldahl acid digestion (G-18997 Rev. 3, multitest MT7) using an Auto Analyzer 3 Spectrophotometer (Omniprocess, Solna, Sweden). Total soil carbon $(\mathrm{C})$ and nitrogen $(\mathrm{N})$ concentrations were analyzed by drying $\left(70{ }^{\circ} \mathrm{C}, 18 \mathrm{~h}\right)$ and grinding samples followed by dry combustion using an EA-IRMS Elemental Analyzer (Flash EA 2000, Thermo Fisher Scientific, Bremen, Germany). For another subsample, soil $\mathrm{pH}$ was determined by using a solution-to soil ratio suspension of $0.01 \mathrm{M}$ $\mathrm{CaCl}_{2}$ mixed with mineral soil $(1: 1)$ or humus (1:10) following Thomas (1996).

\section{Greenhouse Experiment, Experimental Design and Soil Chemistry of Greenhouse Soil}

We performed a greenhouse experiment using soils from each of the three burn severity classes of stands. From September 29 to October 2, 2017 we randomly collected approximately ten circular soil cores (radius $=5 \mathrm{~cm}$; depth $=10 \mathrm{~cm}$ ) within the $314 \mathrm{~m}^{2}$ (radius $=10 \mathrm{~m}$ ) circular area of each of the 21 stands. The different burn severities between stands resulted in variable thickness of the organic horizon, with high severity stands having little or no remaining humus (Mean $20.0 \pm \mathrm{SE} 1.7 \mathrm{~mm}$ ), low burn severity stands having some organic layer $(24.1 \pm 1.9 \mathrm{~mm})$ and unburned stands having thick organic layer $(93.9 \pm 5.5 \mathrm{~mm})$. In order to 
Table 1. Measures of Burn Severity of the Forest Stands.

\begin{tabular}{|c|c|c|c|c|c|}
\hline \multirow[t]{2}{*}{ Burn severity measures } & \multirow[t]{2}{*}{$\mathrm{df}^{1}$} & \multicolumn{2}{|c|}{ Burn severity class of forest stand } & \multirow[t]{2}{*}{$F$-value } & \multirow[t]{2}{*}{$P$-value } \\
\hline & & High & Low & & \\
\hline Tree mortality (\%) & 1,12 & $100.0 \pm 0.0^{\mathrm{a}}$ & $32.1 \pm 5.0^{\mathrm{b}}$ & 186.85 & $<0.001$ \\
\hline Flame height (m) & 1,12 & $6.8 \pm 1.1^{\mathrm{a}}$ & $1.0 \pm 0.1^{\mathrm{b}}$ & 25.62 & $<0.001$ \\
\hline Stem scorch $(\%)$ & 1,12 & $13.1 \pm 3.6^{\mathrm{a}}$ & $2.9 \pm 1.9^{\mathrm{b}}$ & 6.48 & 0.026 \\
\hline Crown scorch $(\%)$ & 1,12 & $99.4 \pm 0.4^{\mathrm{a}}$ & $27.9 \pm 2.4^{\mathrm{b}}$ & 846.74 & $<0.001$ \\
\hline Humus depth ${ }^{2}(\mathrm{~mm})$ & 2,18 & $20.0 \pm 1.7^{\mathrm{a}}$ & $24.1 \pm 1.9^{\mathrm{a}}$ & 142.42 & $<0.001$ \\
\hline Depth of charred soil profile layer (mm) & 1,12 & $10.3 \pm 0.8^{\mathrm{a}}$ & $12.8 \pm 0.8^{\mathrm{b}}$ & 5.03 & 0.045 \\
\hline Charcoal on soil surface $\left(\mathrm{g} / \mathrm{m}^{2}\right)$ & 1,12 & $120 \pm 25$ & $75 \pm 25$ & 1.50 & 0.244 \\
\hline \multicolumn{6}{|c|}{$\begin{array}{l}\text { Mean } \pm S E \text {. } \\
\text { Bold F- and P-values are significant at an alpha value of } 0.05 \text {. } \\
\text { Numbers within rows accompanied by different letters differ significantly at } P \leq 0.05 \text { (following ANOVA). } \\
{ }^{1} \text { Numerator degrees of freedom, denominator degrees of freedom. } \\
{ }^{2} \text { The mean } \pm S E \text { depth of unburned humus was } 93.9 \pm 5.5 \mathrm{~mm} \text { and was statistical significantly higher than both high and low burned soils at } P \leq 0.001 \text { (Bonferroni post } \\
\text { hoc test following ANOVA). }\end{array}$} \\
\hline
\end{tabular}

achieve a representative sample of the conditions that the roots of a developing seedling would experience, we sampled to a fixed depth $(10 \mathrm{~cm})$ at each site which included the humus that was present and the underlying mineral soil. As such, the proportion of organic (humus) soil to mineral soil varied across stands, with the highly burned sites having a low amount of humus relative to the unburned sites. For each stand, all the soil cores were bulked to create a single sample which was then passed twice through a $4.0-\mathrm{mm}$ sieve, placed in a polyethylene bag and transported to Umeå in cooling boxes and stored at $2{ }^{\circ} \mathrm{C}$ until the start of the experiment on October 17, 2017. Two-thirds of the sieved soil from each stand was sent in cooling boxes to SynergyHealth (Etten-Leur, Netherlands), for gamma irradiation at a dose of 43.0-78.8 kGy. This sterilization treatment was chosen to effectively kill all the soil biota while creating minimal disturbance to physical soil structure (McNamara and others 2003).

To distinguish between the effects of soil biota and soil abiotic properties on seedling performance, two separate greenhouse experiments were set up in which tree seedlings were grown in the field collected soils. In the first experiment that tested for the effects of soil properties including live biota, we used unsterilized soil from the field sites to perform a factorial experiment consisting of three soil burn severity classes (that is, high burn, low burn and unburned) $\times$ three tree seedlings species (P. abies, $P$. sylvestris, or B. pendula $) \times$ seven replicates (that is, the seven stands per burn severity class), resulting in a total of 63 pots. For the second experiment that tested for the separated effects of soil biota and abiotic properties, we used sterilized soil originating from the same sites as the first experiment and applied soil community inoculation treatments consisting of live soil from each of the different burn severity classes (Figure 1). The experiment was set up in a factorial design in which pots were filled with sterilized soil from three burn severity classes (high burn, low burn or unburned) and planted with each of three plant species ( $P$. abies, $P$. sylvestris or $B$. pendula); these soils then were inoculated with four burn severity inoculum class treatments. The four inoculum treatments consisted of live inoculum from each class, as well as a sterile control, resulting in 252 pots in total (Figure 1). The experimental units were randomly arranged into blocks, by including one stand of each burn severity class in each block. Thus, each block consisted of 12 pots (three burn severity classes $\times$ four burn severity inoculum classes). Because our research question was focused on local microbial communities and we aimed to generalize results from our experiment to the entire burned landscape we sampled, burn severity inoculum class derived from each stand was kept separate (Gundale and others 2017) and was randomly assigned to receiving soils originating from different stands (Gundale and others 2014). Our inoculation approach therefore followed experiment Type D described by Gundale and others (2017, 2019).

For both experiments, we used $800 \mathrm{ml}$ pots $(8 \times 8 \times 8.5 \mathrm{~cm})$ with holes in the bottom to allow excess water drainage. Pots were filled with $2 / 3$ experimental soil (that is, live soil for the first experiment; sterilized soil + live inoculum for the second experiment) and $1 / 3$ with autoclaved quartz sand to improve drainage after watering. For 
the second experiment, $10 \%$ of the soil volume in each pot with sterilized soil was replaced with soil containing live biota (burn severity inoculum class treatments). This soil was also mixed with autoclaved quartz sand, resulting in an inoculation amount of approximately $6.6 \%$ of the total pot volume. Both unsterilized and sterilized soil from each stand, following mixing with quartz sand, was analyzed for nutrient concentration $\left(\mathrm{NH}_{4}{ }^{+}, \mathrm{NO}_{3}{ }^{+}\right.$, $\mathrm{PO}_{4}{ }^{3-}$ ) using standard protocols (Gundale and others 2011).

All pots were set up on tables in a greenhouse and planted with P. abies, P. sylvestris or B. pendula seedlings. The seeds were obtained from tree nurseries in Sweden and consisted of genetic provenances that corresponded to our field sites.
The seeds were sterilized in 5\% hypochlorite and rinsed with deionized water and then placed on autoclaved quartz sand for pre-germination for seven days. Two seedlings per species were then planted in each pot, and after one month the smallest seedling was removed. During this first month new seedlings were planted if both seedlings in a pot died. After this period, $100 \%$ seedling survival was obtained. The tables were rotated once a week to avoid unwanted effects of greenhouse gradients. Both experiments were run for 4.5 months, and seedlings were watered every day with tap water. The ambient conditions within the greenhouse involved a 18:6 h light/dark photoperiod with a relative air humidity of $40 \%$. The temperature ranged between $25{ }^{\circ} \mathrm{C}$ (day) and

(b) Live soil inoculum from burn severity class of:

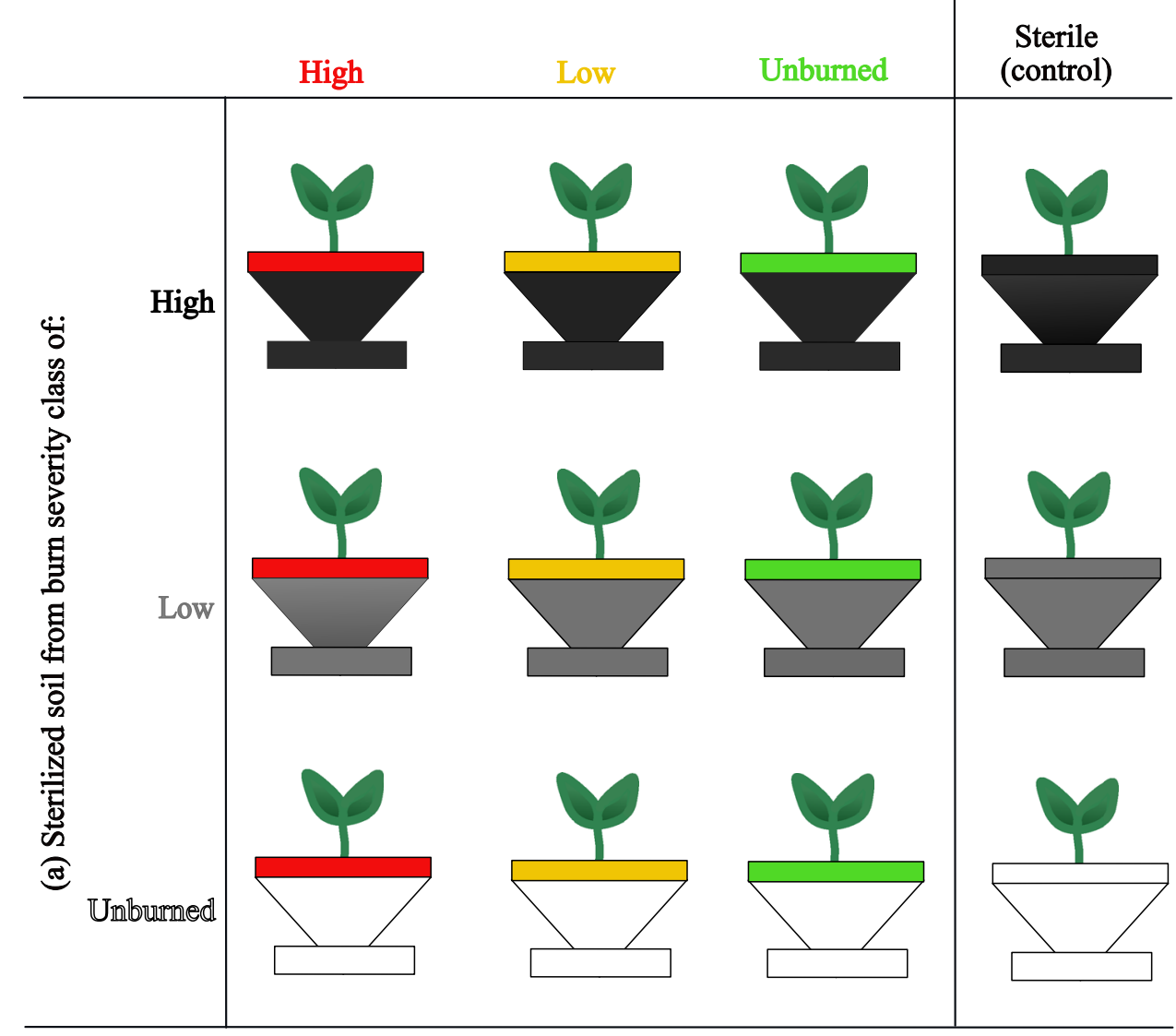

Figure 1. Schematic figure of Experiment 2, which aims to separate the soil biotic and abiotic effects of soils from forest stands subjected to high and low burn severity as well as from unburned stands on the growth of tree seedlings. a Pots with sterilized soil from high burn severity (black pots), low burn severity (gray pots) and unburned (white pots) stands receiving, b live soil inoculum from high severity (red), low severity (yellow) and unburned (green; top vertical) stands. Pots arranged vertically to the far right consist of sterile soil without added inoculum (sterile controls). Each pot was planted with seedling of Picea abies, Pinus sylvestris or Betula pendula. The 12 pots depicted represent one block for one species; in total seven blocks were set up for each of the three species. There were 12 (pots) $\times 3$ (species) $\times 7$ replicates (blocks), resulting in a total of 252 pots for this experiment. The percentage of total soil in each pot that was added live inoculum was $6.6 \%$, except for the sterile control pots where it was $0 \%$. 
$15{ }^{\circ} \mathrm{C}$ (night). At the end of the experiment we harvested the seedlings by eliminating soil from roots with water and cut the plant at the soil surface to separate aboveground from belowground biomass. Plants were put in paper bags and ovendried at $65^{\circ} \mathrm{C}$ for $48 \mathrm{~h}$ and weighed to obtain measures of aboveground, belowground and total biomass.

\section{Statistical Analysis}

For the first experiment, statistical analysis was performed by using split plot ANOVA with burn severity class as a fixed factor and plant species as a subplot factor. For the second experiment we used a blocked design followed by split plot ANOVA with burn severity class and burn severity inoculum class as fixed factors and plant species as a subplot factor. The sites were randomly selected in the field, and we therefore performed the data analysis with an assumption that the data is randomly distributed. To satisfy assumptions of homogeneity of variance, all data were $\log (x)$ transformed. Data for burn severity and soil characteristics of the forest stands, and nutrient concentrations in soil used in greenhouse, were analyzed using one-way ANOVA. For both experiments, stand characteristic and greenhouse soil data, Bonferroni post hoc test was used at $\alpha=0.05$, to further explore pairwise differences between treatment means. All data were statistically analyzed in SPSS version 24 (IBM Corp., Armonk, NY, USA). Raw data are stored as Supplementary material (S3). Figure 1 was created in Affinity Designer 1.8.3.

\section{RESUlts}

\section{Soil Chemical Properties}

In 2018, four years after the fire, we found no significant differences in concentrations or ratios of total soil C, N, C:N and P in mineral soil or organic layer between stands of different burn severities (Table S2). Meanwhile, mineral soil $\mathrm{pH}$ of high burn severity stands $(\mathrm{pH}=3.89 \pm 0.06$; mean \pm $\mathrm{SE})$ and low severity stands $(\mathrm{pH}=3.78 \pm 0.07)$ were both significantly higher than that for unburned stands $(\mathrm{pH}=3.31 \pm 0.12)$ but did not differ from each other $\left(F_{2,18}=12.20, P\right.$-value $\left.\leq 0.001\right)$. For the humus, $\mathrm{pH}$ in low burn severity stands $(\mathrm{pH}=3.30 \pm 0.08)$ was significantly higher than for unburned stands $(\mathrm{pH}=3.04 \pm 0.04)$ $\left(F_{1,12}=8.53, P\right.$-value $\left.=0.013\right)$; humus $\mathrm{pH}$ could not be determined for the high severity stands due to insufficient humus remaining as a consequence of the fire.
For the soil used for the greenhouse experiment, $\mathrm{NH}_{4}{ }^{+}$and $\mathrm{PO}_{4}{ }^{3-}$ were overall greatest in soil from the unburned stands, whereas $\mathrm{NO}_{3}{ }^{-}$was unresponsive to burn severity (Table 2; Figure 2). We also found that sterilization increased $\mathrm{NH}_{4}{ }^{+}$in all soils with the strongest effects on unburned soil. Sterilization also increased soil concentrations of $\mathrm{PO}_{4}{ }^{3-}$, but only in unburned soil, and had no effect on $\mathrm{NO}_{3}{ }^{-}$(Table 2; Figure 2).

\section{Greenhouse Experiments}

In the first experiment in which we used unsterilized soil, both burn severity class and plant species identity significantly affected total, aboveground and belowground seedling biomass, and burn severity class also impacted the aboveground-tobelowground biomass ratio (Table 3); there were no interactive effects between these two factors. The effect of plant species identity was because $B$. pendula and $P$. sylvestris produced more aboveground and belowground biomass than $\operatorname{did} P$. abies (Figure 3). For the burn severity class effect, seedling biomass were generally greater in the unburned soil compared to the high burn severity soil, with low burn severity soils often showing intermediate seedling growth (Figure 3 ). The aboveground-to-belowground biomass ratio was lowest in soil from the high burn severity stands, although this effect of burn severity was detected as significant only by the analysis of variance and not the post hoc analysis (Table 3; Figure 3d).

In the second experiment involving soil sterilization and inoculation of live biota, we found that burn severity class, burn severity inoculum class and plant species identity nearly always had significant effects on seedling total, aboveground and belowground biomass, and on the ratio of aboveground to belowground biomass (Table 4). The plant species effect occurred because $B$. pendula produced the most biomass, while $P$. abies produced the least; $B$. pendula seedlings also had the lowest aboveground-to-belowground biomass ratio (Figure 4). The burn severity effect occurred because seedling growth variables were always highest in unburned soils and usually least in high burn severity soils (Figure $4 a-d$ ). For the significant burn severity inoculum class effects, low burn severity inoculum class often stimulated the highest seedling biomass, and the aboveground-to-belowground biomass ratio, the most out of all inoculum classes (Figure $4 \mathrm{e}-\mathrm{h}$ ). The interactive effect of burn severity and plant species identity was significant for all variables except aboveground biomass (Table 4), which was due to the stronger overall pos- 
Table 2. Results from Analysis of Variance Comparing Main and Interactive Effects of Burn Severity Class (BSC) and Sterilization (S), of Soil Used in the Greenhouse, for $\mathrm{NO}_{3}{ }^{-}, \mathrm{NH}_{4}{ }^{+}$and $\mathrm{PO}_{4}{ }^{3-}$.

\begin{tabular}{|c|c|c|c|c|c|c|c|}
\hline & \multirow[t]{2}{*}{$\mathrm{df}^{1}$} & \multicolumn{2}{|c|}{$\mathrm{NO}_{3}{ }^{-}$} & \multicolumn{2}{|c|}{$\mathrm{NH}_{4}{ }^{+}$} & \multicolumn{2}{|c|}{$\mathrm{PO}_{4}{ }^{3-}$} \\
\hline & & $F$-value & $P$-value & $F$-value & $P$-value & $F$-value & $P$-value \\
\hline Burn severity class (BSC) & 2,18 & 2.470 & 0.099 & 13.747 & $<0.001$ & 9.045 & 0.001 \\
\hline Sterilization (S) & 1,12 & 3.457 & 0.071 & 167.441 & $<0.001$ & 5.554 & 0.024 \\
\hline $\mathrm{BSC} \times \mathrm{S}$ & 2,18 & 2.431 & 0.102 & 17.864 & $<0.001$ & 6.010 & 0.006 \\
\hline
\end{tabular}

itive effect of burn severity on $B$. pendula biomass, and on the aboveground-to-belowground biomass ratio for P. sylvestris and P. abies (Figure 4a-d). We also observed a two-way interactive effect of burn severity inoculum class and plant species and a three-way interactive effect of these two variables and burn severity, on both aboveground biomass and the ratio of aboveground to belowground biomass (Table 4). The two-way interaction (Figure $4 \mathrm{e}-\mathrm{h}$ ) occurred because $B$. pendula responded less to burn severity inoculum class than did the two conifer species. Meanwhile, the three-way interaction occurred because the two conifer species responded stronger to low burn severity inoculum class when grown in the unburned soil compared to the other burn severity classes.

\section{Discussion}

We aimed to test how the abiotic and biotic properties of soil, collected from stands subjected to different burn severity, impact tree seedling growth. Overall, we found that effects of burn severity on both soil biotic and abiotic properties were important for seedling growth, but that effects of soil abiotic properties were overall more important, although seedlings of different tree species varied in their responses to only soil biotic properties. Our findings elucidate how fire may affect seedling performance via its effects on the soil and soil biota, thus providing insights into key mechanisms underlying tree regeneration after wildfire.

\section{Effects of Non-sterile Burn Severity Soil on Tree Seedling Growth}

In our first experiment, where live (non-sterile) soil from each stand was used, we found that both burn severity and plant species identity were important for explaining seedling growth. However, we did not find any interactive effect between burn severity and species identity, meaning that the three species responded similarly to the burn severity treatments. We found that all seedlings grew worse in high burn severity soils and best in unburned soils, with the fast-growing $P$. sylvestris and $B$. pendula seedlings achieving a higher final biomass than those of $P$. abies. These findings contradict those from field experiments showing ground burning of intermediate severity to be more beneficial to growth of pioneer species relative to their growth in unburned soil (Bansal and others 2014). In our study, there were no major differences in concentrations of $\mathrm{NH}_{4}{ }^{+}, \mathrm{NO}_{3}{ }^{-}$and $\mathrm{PO}_{4}{ }^{3-}$ in live soils at the time of collection, probably because we collected our soils four years post-fire, and the expected flush of nutrients immediately following fire (Gundale and others 2005) may have dissipated. However, the greater seedling growth in unburned soils suggests higher nutrient availability in those soils, likely because these soils had a higher proportion of organic material that could be rapidly mineralized in the greenhouse environment.

The seedlings may also have grown largest in the unburned soils because these soils would likely support more ectomycorrhizal and saprotrophic fungi that would stimulate organic matter decomposition and plant access to nutrients which should benefit seedling growth (Holden and others 2016). It has also been suggested that high availability of $\mathrm{C}$ in the root zone from root exudates may stimulate bacterial breakdown of complex sources of $\mathrm{N}$ (Clarholm 1985), meaning that mineralization rates should be higher in soils with active plant roots. At the same time, lower growth of seedlings in high burn severity stands could be due not only to lower resource availability and loss of mutualistic biota, but also to greater levels of fungal pathogens (Hewitt and others 2016). However, our Experiment $l$ is unable to separate between the likely abiotic and biotic mechanisms contributing to these effects. 


\section{Burn severity class}

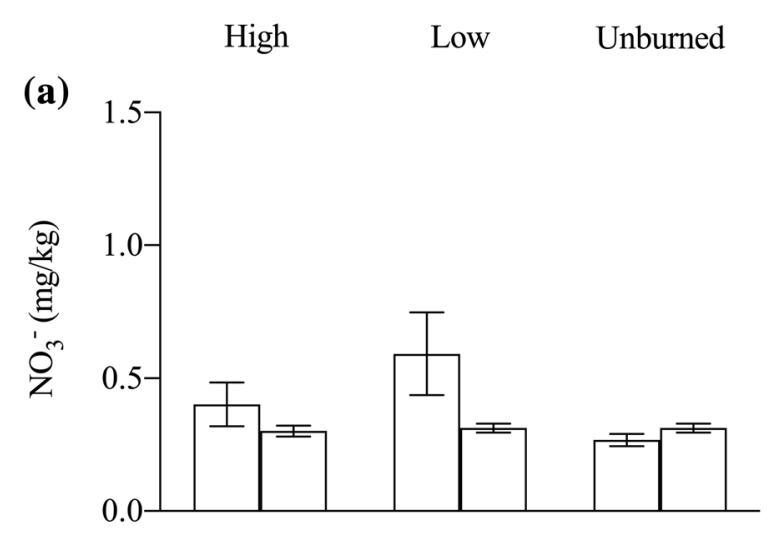

(b)

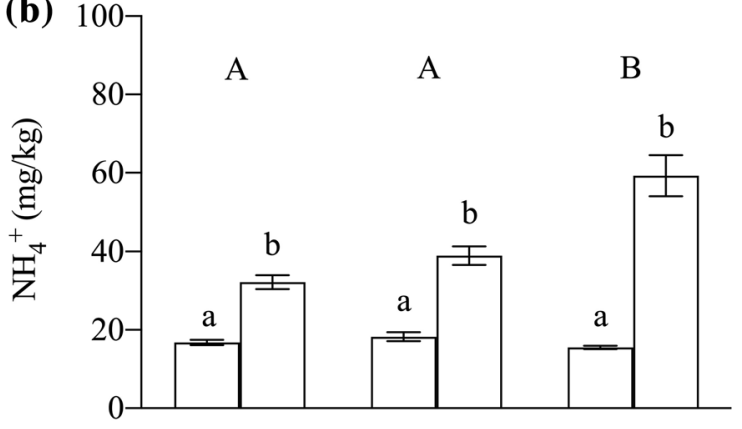

(c)

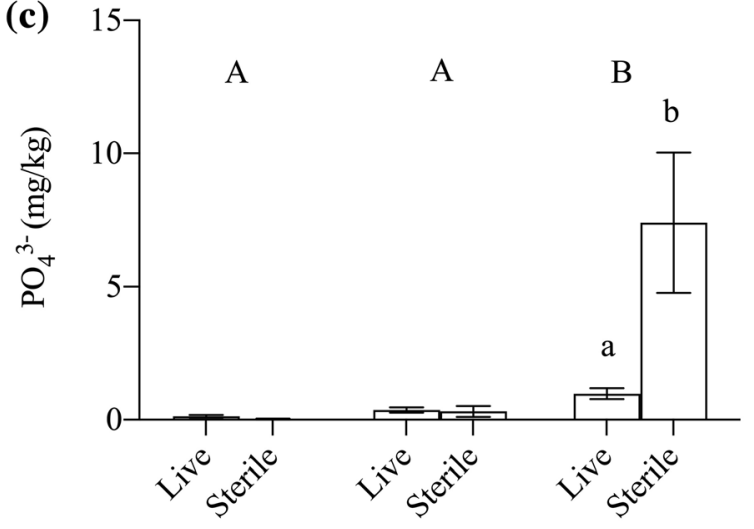

Sterilization

Figure 2. Mean $\pm \mathrm{SE}$ of $\mathrm{NO}_{3}{ }^{-}(\mathbf{a}), \mathrm{NH}_{4}{ }^{+}(\mathbf{b})$ and $\mathrm{PO}_{4}{ }^{3-}$ (c) of live or sterilized mixtures of humus and mineral soil from different forest stand fire severity classes. All soil was mixed with autoclaved sand, at a 2:1 ratio. Different capital letters above pairs of bars indicate significant differences between burn severity classes, and different lower case letters indicate significant differences between live and sterile soil, according to Bonferroni post hoc tests at $P \leq 0.05$. Corresponding two-way ANOVA results ( $F$ and $P$-values) are reported in Table 2.

Our first experiment also revealed that increases in soil $\mathrm{pH}$ associated with fire could indirectly ex- plain seedling growth response to fire, because the burned soil had both the highest soil $\mathrm{pH}$ and the lowest seedling growth. This may be because higher soil $\mathrm{pH}$ can disfavor communities of fungi (Day and others 2019), which would reduce the organic matter decomposition and therefore presumably decrease the availability of nutrients for plant growth (Smith and Read 2008). Our analysis further showed marginally significant statistical differences in seedling aboveground-to-belowground biomass ratios among soil burn severity treatments, and all species tended to have weakly lower ratios when grown in high burn severity soils compared to when grown in low severity and unburned soils, which could reflect greater soil resource limitation. Since the high burn severity soil had much less organic material than in the other soils, it is likely to contain fewer saprotrophic microbes and mycorrhizal fungi needed for promoting nutrient availability for the seedlings, which may have caused them to allocate more biomass to the rooting zone (Ledo and others 2018).

\section{Separating Soil Biotic and Abiotic Influence on Seedling Growth}

Our second experiment (Experiment 2) compared growth of seedlings in sterilized soils across the three burn severity treatments and in sterilized soils that had been reinoculated with live soils (that is, containing live soil biota) from each of the burn severity treatments. This set up enabled us to disentangle the effects of abiotic soil properties from that of live biota.

Similar to the first experiment, we found that burn severity had a highly significant influence on seedling growth of all species, in that seedlings in soil originating from unburned stands grew the most and those in soil from the high burn severity stands grew the least, even when soils were sterilized. We therefore suggest that the availability of nutrients (that is, abiotic soil properties) was the primary driver of growth differences among soils in both experiments. This effect may have occurred in Experiment 1 because there was more organic material in pots with unburned soil that could be mineralized and in Experiment 2 because the sterilization of the soil released nutrients of $\mathrm{NH}_{4}{ }^{+}$ and $\mathrm{PO}_{4}{ }^{3-}$. The higher $\mathrm{PO}_{4}{ }^{3-}$ levels of sterilized unburned soil in our greenhouse experiment may also have contributed to higher uptake of $\mathrm{NH}_{4}{ }^{+}$by seedlings. Blanes and others (2012) showed, although in a field experiment, that when limitation by $\mathrm{P}$ was alleviated, Abies pinsapo seedlings increased their $\mathrm{N}$ uptake. Although we cannot com- 
Table 3. Results from Analysis of Variance Comparing the Main and Interactive Effects of Burn Severity Class (BSC) and Plant Species (PS) on the Total, Aboveground and Belowground Biomass Including the Ratio of Aboveground to Belowground Biomass.

\begin{tabular}{|c|c|c|c|c|c|c|c|c|c|}
\hline & $d f^{1}$ & Total bi & $\operatorname{mass}^{2}$ & $\begin{array}{l}\text { Aboveg } \\
\text { biomass }\end{array}$ & ound & $\begin{array}{l}\text { Belowgi } \\
\text { biomass }\end{array}$ & ound & Aboveg & elowground ${ }^{2,3}$ \\
\hline & & $F$-value & $P$-value & $F$-value & $P$-value & $F$-value & $P$-value & $F$-value & $P$-value \\
\hline $\begin{array}{r}\text { Burn severity } \\
\text { class (BSC) }\end{array}$ & 2,18 & 7.823 & 0.004 & 10.673 & 0.001 & 4.085 & 0.034 & 3.981 & 0.037 \\
\hline Plant species (PS) & 2,36 & 7.900 & $<0.001$ & 6.050 & 0.005 & 9.512 & $<0.001$ & 3.071 & 0.059 \\
\hline $\mathrm{BSC} \times \mathrm{PS}$ & 4,36 & 1.115 & 0.365 & 0.857 & 0.499 & 1.215 & 0.321 & 0.308 & 0.997 \\
\hline
\end{tabular}

Seedlings of Picea abies, Pinus sylvestris and Betula pendula were grown on unsterilized soils from three burn severity classes, that is, from stands of high or low burn severity, or from intact unburned stands.

Bold F- and P-values are significant at an alpha value of 0.05 .

${ }^{1}$ Numerator degrees of freedom, denominator degrees of freedom.

${ }^{2}$ Data were transformed $(\log (x))$ prior to analysis.

${ }^{3}$ The ratio of aboveground to belowground biomass.

pletely exclude the possibility that the responses to soil abiotic conditions could also be because of variation in soil physical properties across our stands, we believe this effect to be minimal and unlikely to vary much among our burn severity treatments. As such, the field collected soil was mixed with $1 / 3$ autoclaved quartz sand to assure water drainage in each pot and to minimize the influence of variation of soil physical properties across our stands.

In partial agreement with our second hypothesis, we found that seedling growth was affected by addition of live inoculum from stands of different burn severities, but in a different way to what we observed for live soil in the first experiment. Specifically, for the two conifer species, we found stronger positive seedling growth responses when inoculum originated from low burn severity sites than from either unburned or high burn severity sites, pointing to the beneficial effects of a low intensity of burning. A possible mechanism is that soil microbes, including ectomycorrhizal fungi, can survive when the organic layer is not completely consumed in a low severity fire (Dahlberg 2002; Holden and others 2016; Day and others 2019), as opposed to in a high severity fire. Further, when overstory trees survive a low severity fire, these trees can maintain the symbiotic relationship with the ectomycorrhizal community (Dahlberg 2002; Pérez-Izquierdo and others 2019), which could allow new seedlings to easily develop new ectomycorrhizal networks after a low burn compared to after a high burn severity fire. Fire may also induce a functional shift in microbial community composition (Clemmensen and others 2015) toward taxa that are more beneficial for seedling growth. For example, Pérez-Izquierdo and others (2021) showed that soils of burned stands, from the same stands as those utilized in this study, were inhabited by ectomycorrhizal species of the genera Sphaerosporella and Laccaria that are known to be fire-adapted and possibly having a higher affinity for inorganic N (LeDuc and others 2013). It is therefore possible that these or other fire-resistant or fire-adapted ectomycorrhizal fungal species, when transferred to the unburned soils, would have benefitted seedlings by improving their access to inorganic $\mathrm{N}$ from this soil. Alternatively, nonmycorrhizal saprotrophs could also have contributed to these effects. As such, our results suggest that conifer tree seedlings are likely to be constrained by the availability of beneficial root associated soil biota (such as non-fire adapted ectomycorrhizal species) or particular saprotrophic microbes in sites that have experienced severe wildfire but not where fire has been less intense (Pérez-Izquierdo and others 2021). This could result in a slow post-fire recovery of important soil biota, and the tree seedlings that depend on them. Finally, soil inoculum from unburned soils had no positive effect on seedling growth of any species in our study. This inoculum is likely to host late-successional ectomycorrhizal fungi such as Russula and Cortinarius (Pérez-Izquierdo and others 2021) important for mobilizing nutrients bound in organic matter complexes (Lindahl and Tunlid 2015). When this inoculum was transplanted to burned soils in the greenhouse, it is plausible that they utilized host plants as their primary source of metabolic C (Corrêa and others 2011), and therefore drainage of $\mathrm{C}$ of seedling origin could have contributed to explain the lower biomass increment of 
Species

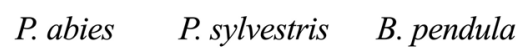

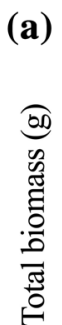
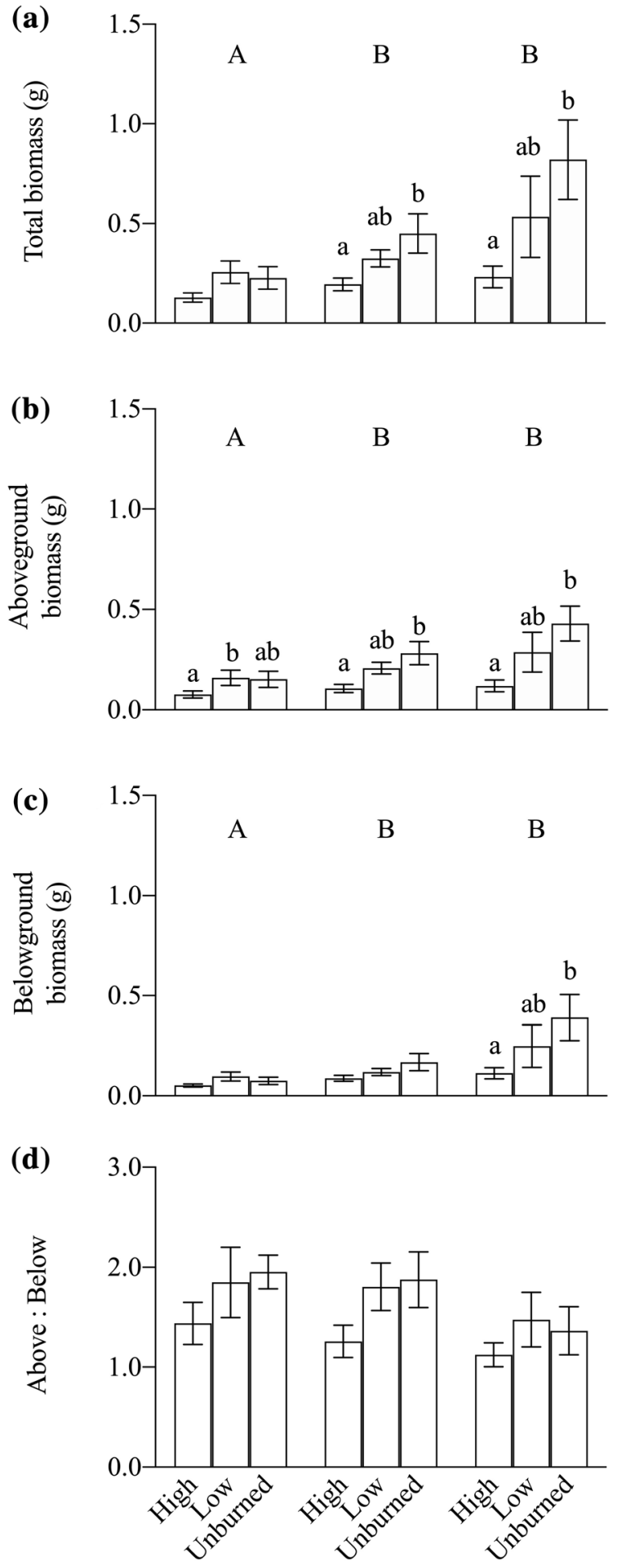

Burn severity class
4Figure 3. Mean \pm SE of total biomass (a), aboveground biomass $(\mathbf{b})$, belowground biomass $(\mathbf{c})$ and the ratio of aboveground to belowground biomass (d) for tree seedlings of Picea abies, Pinus sylvestris and Betula pendula. Seedlings were grown on unsterilized soil originating from stands differing in burn severity (that is, high, low or unburned). Different capital letters above bars indicate significant differences between plant species across burn severity classes, and different lower case letters indicate significant differences between burn severity classes within species, according to Bonferroni post hoc tests at $P \leq 0.05$. Corresponding ANOVA results ( $F$ - and $P$-values) are reported in Table 3 .

seedling grown in burned soils receiving unburned inoculum.

Contrary to our expectations, the late-successional $P$. abies showed the strongest positive response of all three species to soil inoculation (because it responded significantly more to inoculum from low severity burned stands than that from both high burned and unburned stands), with $P$. sylvestris showing an intermediate response, and $B$. pendula showing no response. We expected $P$. sylvestris to respond most strongly to soil burn severity inoculum because of the dominance of this species at our experimental sites, and because live adult trees often facilitate growth of regenerating tree seedlings of the same species (Jonsson and others 1999; Andivia and others 2018), in part through shared ectomycorrhizal connections. However, it is recognized that ectomycorrhizal communities associated with $P$. abies and P. sylvestris partially overlap (Menkis and others 2005), which could explain why seedlings of both conifers (but not $B$. pendula) responded positively to the low burn severity inoculum class relative to at least some of the other inoculum treatments. Our finding that $P$. abies and P. sylvestris do not perform well on highly burned soils in the absence of a live community of microorganisms may explain regeneration of conifers is sometimes disfavored following fire in Swedish forests (Elfving 1983; Kardell and Laestadius 1987). Unlike the two conifer species, B. pendula never responded to soil inoculation treatments. B. pendula is a fast-colonizing species on fire disturbed areas (Hellberg and others 2003; Gustafsson and others 2019), and its post-fire abundance has often been interpreted in terms of it being a good resource competitor (Dehlin and others 2004) that is effective at exploiting initial elevated levels of inorganic $\mathrm{N}$ resulting from fire disturbance (Gundale and others 2005). Findings from our study suggest $B$. pendula 
Table 4. Results from Analysis of Variance Comparing the Main and Interactive Effects of Burn Severity Class (BSC), Burn Severity Inoculum Class (IC) and Plant Species (PS) on the Total, Aboveground and Belowground Tree Seedling Biomass, and the Ratio of Aboveground to Belowground Seedling Biomass.

\begin{tabular}{|c|c|c|c|c|c|c|c|c|c|}
\hline & \multirow[t]{2}{*}{$d f^{1}$} & \multicolumn{2}{|c|}{ Total biomass ${ }^{2}$} & \multicolumn{2}{|c|}{$\begin{array}{l}\text { Aboveground } \\
\text { biomass }^{2}\end{array}$} & \multicolumn{2}{|c|}{$\begin{array}{l}\text { Belowground } \\
\text { biomass }^{2}\end{array}$} & \multicolumn{2}{|c|}{ Aboveground/belowground ${ }^{2,3}$} \\
\hline & & $F$-value & $P$-value & $F$-value & $P$-value & $F$-value & $P$-value & $F$-value & $P$-value \\
\hline $\begin{array}{l}\text { Burn severity } \\
\text { class (BSC) }\end{array}$ & 2,66 & 50.402 & $<0.001$ & 58.972 & $<0.001$ & 38.331 & $<0.001$ & 27.900 & $<0.001$ \\
\hline $\begin{array}{l}\text { Burn severity } \\
\text { inoculum } \\
\text { class (IC) }\end{array}$ & 3,66 & 2.993 & 0.037 & 3.534 & 0.019 & 2.002 & 0.122 & 3.134 & 0.031 \\
\hline $\begin{array}{l}\text { Plant species } \\
\text { (PS) }\end{array}$ & 2,144 & 189.502 & $<0.001$ & 165.750 & $<0.001$ & 198.825 & $<0.001$ & 23.050 & $<0.001$ \\
\hline $\mathrm{BSC} \times \mathrm{IC}$ & 6,66 & 1.331 & 0.256 & 1.235 & 0.300 & 1.362 & 0.243 & 0.174 & 0.983 \\
\hline $\mathrm{BSC} \times \mathrm{PS}$ & 4,144 & 3.092 & 0.018 & 1.717 & 0.149 & 4.878 & 0.001 & 3.390 & 0.011 \\
\hline $\mathrm{IC} \times \mathrm{PS}$ & 6,144 & 1.189 & 0.087 & 2.703 & 0.016 & 0.990 & 0.434 & 2.701 & 0.016 \\
\hline $\mathrm{BSC} \times \mathrm{IC} \times \mathrm{PS}$ & 12,144 & 1.469 & 0.142 & 1.941 & 0.034 & 1.167 & 0.312 & 2.883 & 0.001 \\
\hline Block & 12,66 & 4.400 & 0.006 & 3.620 & 0.004 & 2.849 & 0.016 & 1.972 & 0.082 \\
\hline $\begin{array}{l}\text { Bold F-and P-values a } \\
\text { from three burn severit } \\
\text { biotic drivers (soil biota } \\
\text { or unburned) or with } \\
{ }^{1} \text { Numerator degrees of } \\
{ }^{2} \text { Data were transforme } \\
{ }^{3} \text { The ratio of abovegrol }\end{array}$ & $\begin{array}{l}\text { e significant } \\
\text { classes, that } \\
\text { on seedling } \\
\text { terile soil. } \\
\text { freedom, den } \\
\text { (log }(x)) \text { pri } \\
\text { ind to belows }\end{array}$ & $\begin{array}{l}\text { t an alpha val } \\
\text { s, from stands } \\
\text { rowth, all ster } \\
\text { minator degree } \\
\text { to analysis. } \\
\text { ound biomass. }\end{array}$ & $\begin{array}{l}\text { ue of } 0.05 \text {. Seed } \\
\text { with high or lo } \\
\text { lized soils were } \\
\text { s of freedom. }\end{array}$ & $\begin{array}{l}\text { ings of Picea } \\
\text { burn severit } \\
\text { reinoculated }\end{array}$ & $\begin{array}{l}\text { bies, Pinus sy } \\
\text { or, from unt } \\
\text { ith live soil fr }\end{array}$ & $\begin{array}{l}\text { stris and Bet } \\
\text { ned stands. } \\
\text { i different } c l\end{array}$ & $\begin{array}{l}\text { a pendula } \\
\text { order to sep } \\
\text { ses (that is, }\end{array}$ & $\begin{array}{l}\text { grown on } \\
\text { ite effects of } \\
\text { ids with hi. }\end{array}$ & $\begin{array}{l}\text { amma irradiated) soils } \\
\text { ers (burn severity) and } \\
\text { erity, low burn severity }\end{array}$ \\
\hline
\end{tabular}

seedlings responded strongly to conditions of elevated nutrients and appeared less dependent than the conifers on ectomycorrhizal associations or other microorganisms for nutrient uptake during their establishment phase. However, this warrants further exploration given that mycorrhizal fungi have previously been shown to influence growth of $B$. pendula seedlings in boreal forests (Jonsson and others 2001). Deciduous trees such as B. pendula are expected to become more dominant in the forested landscape if climate warming increases and higher burn severity conditions prevail (Mekonnen and others 2019; Mack and others 2021). Our study suggests that this is mainly because Betula pendula seedlings are largely unresponsive to live soil biota and are therefore positioned to perform well directly after a fire in high burn severity sites even when the soil biota has been lost. B. pendula may not be disfavored from the absence of soil biota to the same extent as P. sylvestris and P. abies may be.

\section{Conclusions}

In this study we disentangled the effect of soil abiotic and biotic properties on tree seedling performance following wildfire to evaluate the effect of fire disturbance on the regeneration of boreal forests and shed light on the underlying mecha- nisms. Our results have several implications. First, they highlight that regeneration of $B$. pendula is unresponsive to changes in soil biota and is instead mostly driven by changes in abiotic soil properties. In contrast, both $P$. abies and $P$. sylvestris were responsive to soil biota from low burn severity soil relative to biota from the other soils; this demonstrates that low severity fire disturbances in part benefit post-fire regeneration of conifers due to the presence of specific soil biota that benefit from low burn severity fire. However, all seedlings responded positively when soil nutrients were elevated and grew well in the absence of biota, suggesting that soil nutrient conditions following fire would likely have an overriding importance for the regeneration success of all species shortly after fire. Second, studies such as ours can inform on strategic postfire management decisions that involve restoration or assisted forest regeneration. When low burn severity fires occur, including during management procedures that incorporate prescribed burning prior to forest replanting, there is a need to consider its consequences for soil biota and how this biota in turn impacts on conifer seedling growth and regeneration. Finally, our work provides evidence of the relative importance of biotic and abiotic drivers of tree seedling regeneration following fire disturbance, and how these drivers are in turn 


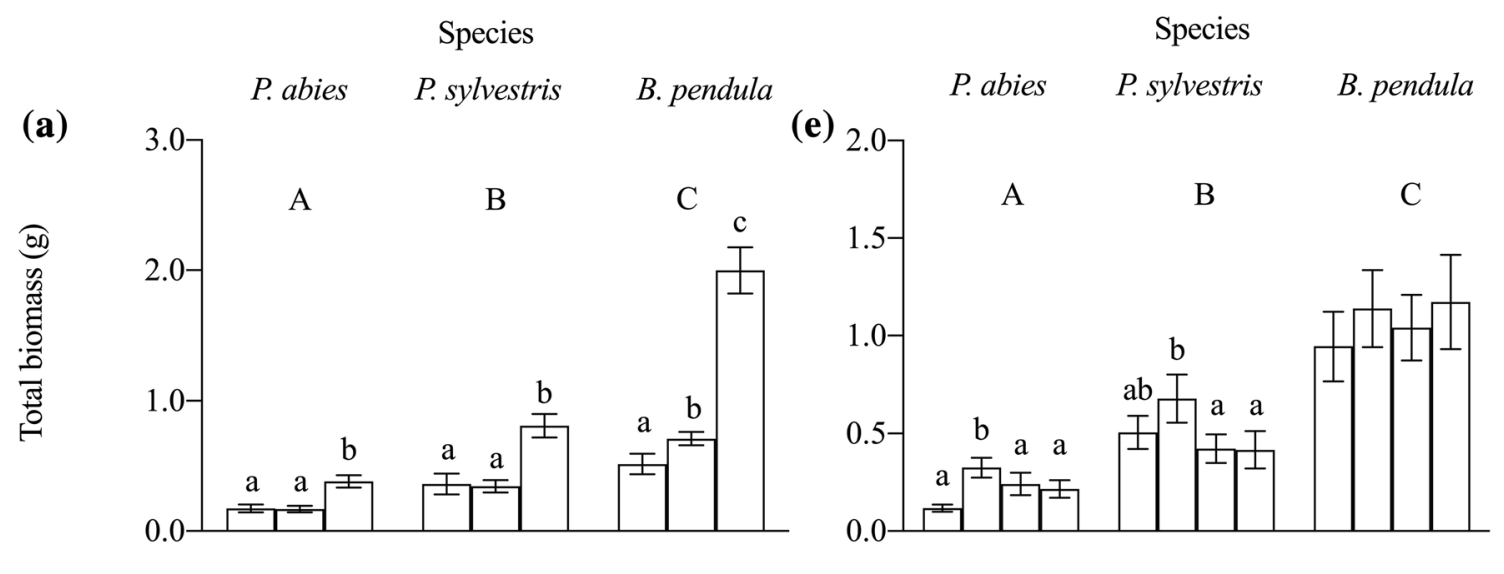

(b)

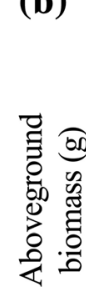

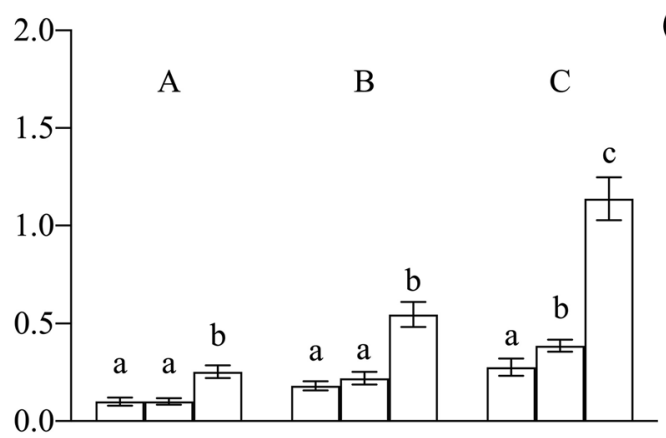

(f) 2

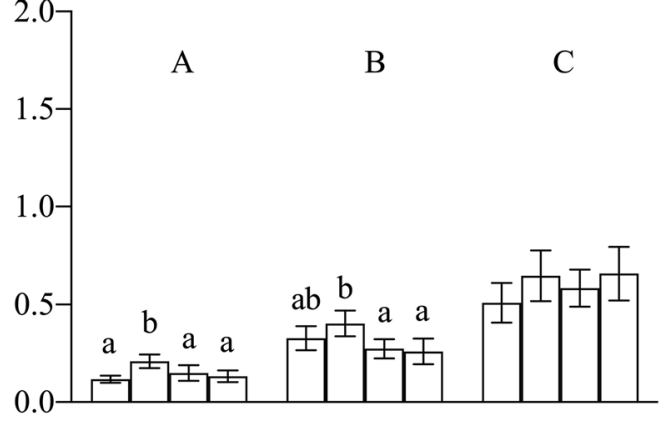

(c) $\quad 2.07$

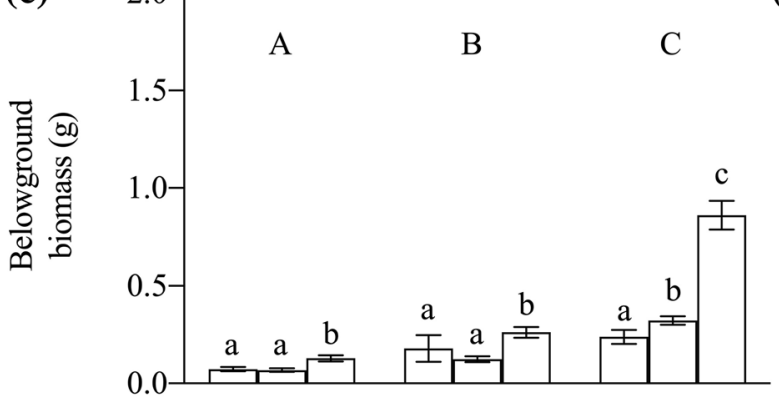

(g) 2

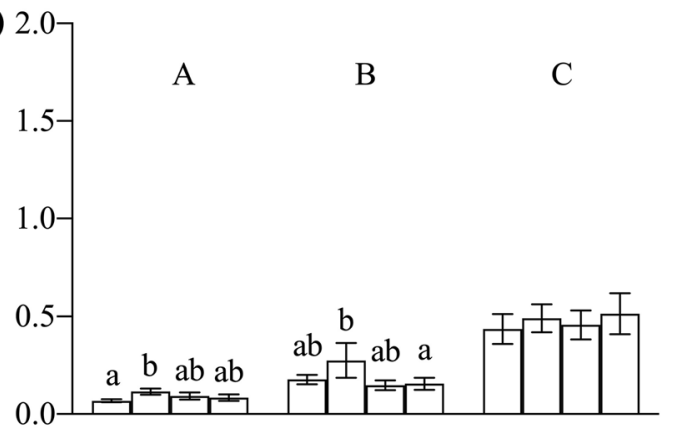

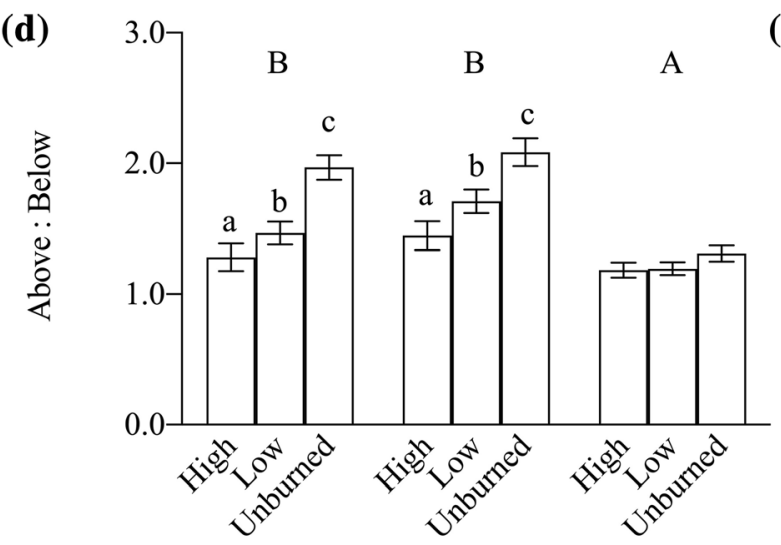

Burn severity class (h)

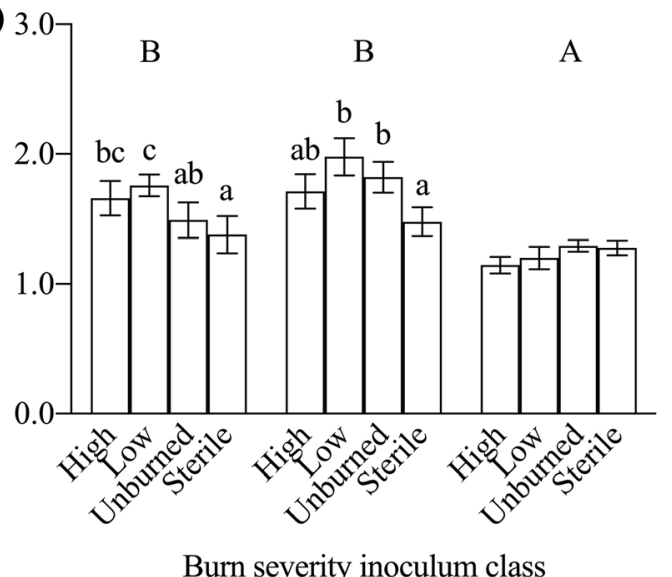


४Figure 4. Mean $\pm \mathrm{SE}$ of total biomass (a, e), aboveground biomass (b, f), belowground biomass (c, $\mathbf{g})$, ratio of aboveground to belowground biomass $(\mathbf{d}, \mathbf{h})$ for tree seedlings of Picea abies, Pinus sylvestris and Betula pendula. Seedlings were grown on sterilized (gamma irradiated) soil, originating from stands differing in burn severity (that is, high, low and unburned), and with the sterilized soil then reinoculated with live soil from stands differing in burn severity (high, low and unburned) or with sterile soil. Different capital letters above bar groups indicate significant differences between plant species across burn severity inoculum class treatments, and small letters within bar groups indicate significant differences for burn severity classes (a-d) or burn severity inoculum class treatments $(\mathbf{e}-\mathbf{h})$ according to Bonferroni post hoc tests at $P \leq 0.05$. Corresponding ANOVA results $(F$ - and $P$-values) are reported in Table 4 .

impacted by burn severity. Understanding how burn severity impacts the interplay of these abiotic and biotic soil factors is of particular importance in understanding the mechanisms by which future climate change may influence forest regeneration, given that climate warming is expected to lead to both more frequent and more severe fires in the boreal region. As climate warming is being accompanied by novel fire behavior regimes, there is a growing need to further understand the role played by both soil abiotic factors and the soil microbial community in promoting early seedling establishment under different fire scenarios.

\section{ACKNOWLEDGEMENTS}

The research was funded by Formas (ID 20158544-30572-25) and a TC4F (Trees and Crops for the Future) grant to MCN. We wish to thank Kelley Gundale for assistance in the greenhouse, Morgan Karlsson and Marie-Lou Novene for assisting with the collection of soil samples and Marie-Lou Novene for laboratory help.

\section{FUNDING}

Open access funding provided by Swedish University of Agricultural Sciences.

\section{Declarations}

Conflict of interest The authors declare that they have no conflict of interest.

\section{OPEN ACCESS}

This article is licensed under a Creative Commons
Attribution 4.0 International License, which permits use, sharing, adaptation, distribution and reproduction in any medium or format, as long as you give appropriate credit to the original author(s) and the source, provide a link to the Creative Commons licence, and indicate if changes were made. The images or other third party material in this article are included in the article's Creative Commons licence, unless indicated otherwise in a credit line to the material. If material is not included in the article's Creative Commons licence and your intended use is not permitted by statutory regulation or exceeds the permitted use, you will need to obtain permission directly from the copyright holder. To view a copy of this licence, visit $h$ ttp://creativecommons.org/licenses/by/4.0/.

\section{REFERENCES}

Alexander HD, Natali SM, Loranty MM, Ludwig SM, Spektor VV, Davydov S, Zimov N, Trujillo I, Mack MC. 2018. Impacts of increased soil burn severity on larch forest regeneration on permafrost soils of far northeastern Siberia. Forest Ecology and Management 417:144-53. https://doi.org/10.1016/j.forec o.2018.03.008

Allison SD, Treseder KK. 2011. Climate change feedbacks to microbial decomposition in boreal soils. Fungal Ecology 4(6):362-74. https://doi.org/10.1016/j.funeco.2011.01.003.

Andivia E, Madrigal-González J, Villar-Salvador P, Zavala MA. 2018. Do adult trees increase conspecific juvenile resilience to recurrent droughts? Implications for Forest Regeneration. Ecosphere 9(6):e02282. https://doi.org/10.1002/ecs2.2282.

Angelstam P, Kuuluvainen T. 2004. Boreal forest disturbance regimes, successional dynamics and landscape structures: a European perspective. Ecological Bulletins:117-36.

Atkinson MD. 1992. Betula pendula Roth (B. verrucosa Ehrh.) and B. pubescens Ehrh. Journal of Ecology 80:837-70. https://doi. org/10.2307/2260870.

Balshi MS, McGuire AD, Duffy P, Flannigan M, Walsh J, Melillo J. 2009. Assessing the response of area burned to changing climate in western boreal North America using a Multivariate Adaptive Regression Splines (MARS) approach. Global Change Biology 15(3):578-600. https://doi.org/10.1111/j.13 65-2486.2008.01679.x.

Bansal S, Jochum T, Wardle DA, Nilsson MC. 2014. The interactive effects of surface-burn severity and canopy cover on conifer and broadleaf tree seedling ecophysiology. Canadian Journal of Forest Research 44(9):1032-41. https://doi.org/10. 1139/cjfr-2014-0112.

Bárcenas-Moreno G, García-Orenes F, Mataix-Solera J, MataixBeneyto J, Bååth E. 2011. Soil microbial recolonisation after a fire in a Mediterranean forest. Biology and Fertility of Soils 47(3):261-72. https://doi.org/10.1007/s00374-010-0532-2.

Bergner B, Johnstone J, Treseder KK. 2004. Experimental warming and burn severity alter soil $\mathrm{CO} 2$ flux and soil functional groups in a recently burned boreal forest. Global Change Biology 10.12:1996-2004. https://onlinelibrary.wiley.com/doi/full/https://doi.org/10.1111/j.1365-2486.2004.00 868.x 
Blanes MC, Emmett BA, Viñegla B, Carreira JA. 2012. Alleviation of $\mathrm{P}$ limitation makes tree roots competitive for $\mathrm{N}$ against microbes in a $\mathrm{N}$-saturated conifer forest: a test through $\mathrm{P}$ fertilization and $15 \mathrm{~N}$ labelling. Soil Biology and Biochemistry 48:51-9. https://doi.org/10.1016/j.soilbio.2012.01.012.

Certini G. 2005. Effects of fire on properties of forest soils: a review. Oecologia 143(1):1-10. https://doi.org/10.1007/s004 42-004-1788-8.

Clarholm M. 1985. Interactions of bacteria, protozoa and plants leading to mineralization of soil nitrogen. Soil Biology and Biochemistry 17(2):181-7. https://doi.org/10.1016/0038-071 7(85)90113-0.

Clemmensen KE, Finlay RD, Dahlberg A, Stenlid J, Wardle DA, Lindahl BD. 2015. Carbon sequestration is related to mycorrhizal fungal community shifts during long-term succession in boreal forests. New Phytologist 205(4):1525-36. https://doi. org/10.1111/nph.13208.

Corrêa A, Hampp R, Magel E, Martins-Loução MA. 2011. Carbon allocation in ectomycorrhizal plants at limited and optimal $\mathrm{N}$ supply: an attempt at unraveling conflicting theories. Mycorrhiza 21(1):35-51. https://doi.org/10.1007/s00572-010 $-0309-3$.

Czimczik CI, Schmidt MWI, Schulze ED. 2005. Effects of increasing fire frequency on black carbon and organic matter in Podzols of Siberian Scots pine forests. European Journal of Soil Science 56(3):417-28. https://doi.org/10.1111/j.1365-23 89.2004.00665.x.

Dahlberg A. 2002. Effects of fire on ectomycorrhizal fungi in Fennoscandian boreal forests. Silva Fennica 36(1):69-80.

Dahlberg A, Schimmel J, Taylor AF, Johannesson H. 2001. Postfire legacy of ectomycorrhizal fungal communities in the Swedish boreal forest in relation to fire severity and logging intensity. Biological Conservation 100(2):151-61. https://doi. org/10.1016/S0006-3207(00)00230-5.

Day NJ, Dunfield KE, Johnstone JF, Mack MC, Turetsky MR, Walker XJ, White AL, Baltzer JL. 2019. Wildfire severity reduces richness and alters composition of soil fungal communities in boreal forests of western Canada. Global Change Biology 25(7):2310-24. https://doi.org/10.1111/gcb.14641.

de Groot WJ, Flannigan MD, Cantin AS. 2013. Climate change impacts on future boreal fire regimes. Forest Ecology and Management 294:35-44. https://doi.org/10.1016/j.foreco.201 2.09.027.

Dehlin H, Nilsson MC, Wardle DA, Shevtsova A. 2004. Effects of shading and humus fertility on growth, competition, and ectomycorrhizal colonization of boreal forest tree seedlings. Canadian Journal of Forest Research 34(12):2573-86. http s://doi.org/10.1139/x04-143.

DeLuca T, Nilsson MC, Zackrisson O. 2002. Nitrogen mineralization and phenol accumulation along a fire chronosequence in northern Sweden. Oecologia 133(2):206-14. https://doi.or g/10.1007/s00442-002-1025-2.

Elfving B. 1983. Den nya skogens produktion. Sveriges Skogsvårdsförbunds Tidskrift 83(4-5):7-16.

Gillett NP, Weaver AJ, Zwiers FW, Flannigan MD. 2004. Detecting the effect of climate change on Canadian forest fires. Geophysical Research Letters 31:18. https://doi.org/10.1029/ 2004GL020876.

Gómez-Rey MX, Gonzalez-Prieto SJ. 2013. Short-term impact of a wildfire on net and gross $\mathrm{N}$ transformation rates. Biology and Fertility of Soils 49(8):1065-75. https://doi.org/10.1007/ s00374-013-0806-6.
Granström A. 1991. Skogen efter branden. Skog \& Forskning $4(91): 32-8$.

Gundale MJ, DeLuca TH, Fiedler CE, Ramsey PW, Harrington MG, Gannon JE. 2005. Restoration treatments in a Montana ponderosa pine forest: effects on soil physical, chemical and biological properties. Forest Ecology and Management 213(13):25-38. https://doi.org/10.1016/j.foreco.2005.03.015.

Gundale MJ, Fajardo A, Lucas RW, Nilsson MC, Wardle DA. 2011. Resource heterogeneity does not explain the diversityproductivity relationship across a boreal island fertility gradient. Ecography 34(5):887-96. https://doi.org/10.1111/j.16000587.2011.06853.x.

Gundale MJ, Kardol P, Nilsson MC, Nilsson U, Lucas RW, Wardle DA. 2014. Interactions with soil biota shift from negative to positive when a tree species is moved outside its native range. New Phytologist 202(2):415-21. https://doi.org/ $10.1111 /$ nph.12699.

Gundale MJ, Wardle DA, Kardol P, Nilsson MC. 2019. Comparison of plant-soil feedback experimental approaches for testing soil biotic interactions among ecosystems. New Phytologist 221(1):577-87. https://doi.org/10.1111/nph.15367.

Gundale MJ, Wardle DA, Kardol P, Van der Putten WH, Lucas RW. 2017. Soil handling methods should be selected based on research questions and goals. New Phytologist 216(1):18-23. https://doi.org/10.1111/nph.14659.

Gustafsson L, Berglind M, Granström A, Grelle A, Isacsson G, Kjellander P, Larsson S, Lindh M, Pettersson LB, Strengbom J, Stridh B, Sävström T, Thor G, Wikars LO, Mikusiński G. 2019. Rapid ecological response and intensified knowledge accumulation following a north European mega-fire. Scandinavian Journal of Forest Research 34(4):234-53. https://doi.org/ $10.1080 / 02827581.2019 .1603323$.

Hellberg E, Hörnberg G, Östlund L, Zackrisson O. 2003. Vegetation dynamics and disturbance history in three deciduous forests in boreal Sweden. Journal of Vegetation Science 14(2):267-76. https://doi.org/10.1111/j.1654-1103.2003.tb02 152.x.

Hewitt RE, Chapin FS III, Hollingsworth TN, Mack MC, Rocha AV, Taylor DL. 2020. Limited overall impacts of ectomycorrhizal inoculation on recruitment of boreal trees into Arctic tundra following wildfire belie species-specific responses. PloS One 15(7):e0235932. https://doi.org/10.1371/journal.pone.0 235932.

Hewitt RE, Chapin FS III, Hollingsworth TN, Taylor DL. 2017. The potential for mycobiont sharing between shrubs and seedlings to facilitate tree establishment after wildfire at Alaska arctic treeline. Molecular Ecology 26(14):3826-38. h ttps://doi.org/10.1111/mec.14143.

Hewitt RE, Hollingsworth TN, Chapin FS III, Taylor DL. 2016. Fire-severity effects on plant-fungal interactions after a novel tundra wildfire disturbance: implications for arctic shrub and tree migration. BMC Ecology 16(1):1-11. https://doi.org/10. 1186/s12898-016-0075-y.

Holden SR, Gutierrez A, Treseder KK. 2013. Changes in soil fungal communities, extracellular enzyme activities, and litter decomposition across a fire chronosequence in Alaskan boreal forests. Ecosystems 16(1):34-46. https://doi.org/10.1007/s10 021-012-9594-3.

Holden SR, Rogers BM, Treseder KK, Randerson JT. 2016. Fire severity influences the response of soil microbes to a boreal forest fire. Environmental Research Letters 11(3):035004. h ttps://doi.org/10.1088/1748-9326/11/3/035004. 
Johnstone JF, Hollingsworth TN, Chapin FS III, Mack MC. 2010. Changes in fire regime break the legacy lock on successional trajectories in Alaskan boreal forest. Global Change Biology 16(4):1281-95. https://doi.org/10.1111/j.1365-2486.2009.02 051.x.

Jonsson L, Dahlberg A, Nilsson MC, Kårén O, Zackrisson O. 1999. Continuity of ectomycorrhizal fungi in self-regenerating boreal Pinus sylvestris forests studied by comparing mycobiont diversity on seedlings and mature trees. The New Phytologist 142(1):151-62. https://doi.org/10.1046/j.1469-8137.1999.00 383.x.

Jonsson L, Nilsson MC, Wardle DA, Zackrisson O. 2001. Context dependent effects of ectomycorrhizal species richness on tree seedling productivity. Oikos 93(3):353-64. https://doi.org/10. 1034/j.1600-0706.2001.930301.x.

Kardell L, Laestadius L. 1987. Longterm yield of Norway spruce (Picea abies L.) after prescribed burning. An example from Mid-Sweden. Sveriges Skogsvårdsförbunds Tidskrift (Sweden)

Kasischke ES, Turetsky MR. 2006. Recent changes in the fire regime across the North American boreal region-Spatial and temporal patterns of burning across Canada and Alaska. Geophysical Research Letters 3:9. https://doi.org/10.1029/20 06 GL025677.

Lampainen J, Kuuluvainen T, Wallenius TH, Karjalainen L, Vanha-Majamaa I. 2004. Long-term forest structure and regeneration after wildfire in Russian Karelia. Journal of Vegetation Science 15(2):245-56. https://doi.org/10.1111/j.l 654-1103.2004.tb02259.x.

Ledo A, Paul KI, Burslem DFRP, Ewel JJ, Barton C, Battaglia M, Brooksbank K, Carter J, Eid TH, England JR, Fitzgerald A, Jonson J, Mencuccini M, Montagu KD, Montero G, Mugasha WA, Pinkard E, Roxburgh S, Ryan CM, Ruiz-Peinado R, Sochacki S, Specht A, Wildy D, Wirth C, Zerihun A, Chave J. 2018. Tree size and climatic water deficit control root to shoot ratio in individual trees globally. New Phytologist 217(1):811. https://doi.org/10.1111/nph.14863.

LeDuc SD, Lilleskov EA, Horton TR, Rothstein DE. 2013. Ectomycorrhizal fungal succession coincides with shifts in organic nitrogen availability and canopy closure in post-wildfire jack pine forests. Oecologia 172(1):257-69. https://doi.org/10.100 7/s00442-012-2471-0.

Lidskog R, Johansson J, Sjödin D. 2019. Wildfires, responsibility and trust: public understanding of Sweden's largest wildfire. Scandinavian Journal of Forest. Research 34(4):319-28. http s://doi.org/10.1080/02827581.2019.1598483.

Lindahl BD, Tunlid A. 2015. Ectomycorrhizal fungi-potential organic matter decomposers, yet not saprotrophs. New Phytologist 205(4):1443-7. https://doi.org/10.1111/nph.13201.

Mack MC, Walker XJ, Johnstone JF, Alexander HD, Melvin AM, Jean M, Miller SN. 2021. Carbon loss from boreal forest wildfires offset by increased dominance of deciduous trees. Science 372(6539):280-3. https://doi.org/10.1126/science.abf 3903.

Mataix-Solera J, Guerrero C, García-Orenes F, Bárcenas GM, Torres MP. 2009. Forest fire effects on soil microbiology. Fire Effects on Soils and Restoration Strategies 5:133-75. https://d oi.org/10.1201/9781439843338.

McNamara NP, Black HIJ, Beresford NA, Parekh NR. 2003. Effects of acute gamma irradiation on chemical, physical and biological properties of soils. Applied Soil Ecology 24(2):11732. https://doi.org/10.1016/S0929-1393(03)00073-8.
Mekonnen ZA, Riley WJ, Randerson JT, Grant RF, Rogers BM. 2019. Expansion of high-latitude deciduous forests driven by interactions between climate warming and fire. Nature Plants 5(9):952-8. https://doi.org/10.1038/s41477-019-0495-8.

Menkis A, Vasiliauskas R, Taylor AF, Stenlid J, Finlay R. 2005. Fungal communities in mycorrhizal roots of conifer seedlings in forest nurseries under different cultivation systems, assessed by morphotyping, direct sequencing and mycelial isolation. Mycorrhiza 16(1):33-41. https://doi.org/10.1007/ s00572-005-0011-z.

Nilsson U, Elfving B, Karlsson K. 2012. Productivity of Norway spruce compared to Scots pine in the interior of northern Sweden. Silva Fennica 46(2):197-209.

Pérez-Izquierdo L, Clemmensen KE, Strengbom J, Granath G, Wardle DA, Nilsson MC, Lindahl BD. 2021. Crown-fire severity is more important than ground-fire severity in determining soil fungal community development in the boreal forest. Journal of Ecology 109(1):504-18. https://doi.org/10. $1111 / 1365-2745.13529$.

Pérez-Izquierdo L, Clemmensen KE, Strengbom J, Nilsson MC, Lindahl BD. 2019. Quantification of tree fine roots by realtime PCR. Plant and Soil 440:1-8. https://doi.org/10.1007/s1 1104-019-04096-9.

Ponomarev EI, Kharuk VI, Ranson KJ. 2016. Wildfires dynamics in Siberian larch forests. Forests 7(6):125. https://doi.org/10. $3390 / f 7060125$.

Pumpanen JS, Heinonsalo J, Rasilo T, Hurme KR, Ilvesniemi H. 2009. Carbon balance and allocation of assimilated CO 2 in Scots pine, Norway spruce, and Silver birch seedlings determined with gas exchange measurements and $14 \mathrm{C}$ pulse labelling. Trees 23(3):611-21. https://doi.org/10.1007/s00468008-0306-8.

Read DJ, Leake JR, Perez-Moreno J. 2004. Mycorrhizal fungi as drivers of ecosystem processes in heathland and boreal forest biomes. Canadian Journal of Botany 82(8):1243-63. https://d oi.org/10.1139/b04-123.

Smith SE, Read D. 2008. Mycorrhizal Symbiosis, 3rd edn. London: Academic press.

Soja AJ, Tchebakova NM, French NH, Flannigan MD, Shugart HH, Stocks BJ, Sukhinin AI, Parfenova EI, Chapin FS III, Stackhouse PW Jr. 2007. Climate-induced boreal forest change: predictions versus current observations. Global and Planetary Change 56(3-4):274-96. https://doi.org/10.1016/j.g loplacha.2006.07.028.

Stephens SL, Agee JK, Fule PZ, North MP, Romme WH, Swetnam TW, Turner MG. 2013. Managing forests and fire in changing climates. Science 342(6154):41-2. https://doi.org/1 $0.1126 /$ science. 1240294 .

Sun H, Santalahti M, Pumpanen J, Köster K, Berninger F, Raffaello T, Jumpponen A, Asiegbu FO, Heinonsalo J. 2015. Fungal Community Shifts in Structure and Function across a Boreal Forest Fire Chronosequence. Applied and Environmental Microbiology 81:7869-80. https://doi.org/10.1128/A EM.02063-15.

Thomas GW. 1996. Soil pH and soil acidity. Methods of soil analysis: part 3 chemical methods 5:475-90. https://doi.org/ 10.2136/sssabookser5.3.cl6

Treseder KK, Mack MC, Cross A. 2004. Relationships among fires, fungi, and soil dynamics in Alaskan boreal forests. Ecological Applications 14(6):1826-38. https://doi.org/10.1890/0 3-5133. 
Wan S, Hui D, Luo Y. 2001. Fire effects on nitrogen pools and dynamics in terrestrial ecosystems: a meta-analysis. Ecological Applications 11(5):1349-65. https://doi.org/10.1890/1051-07 61(2001)011[1349:FEONPA]2.0.CO;2.
Zackrisson O. 1977. Influence of forest fires on the North Swedish boreal forest. Oikos 29:22-32. https://doi.org/10.23 07/3543289. 